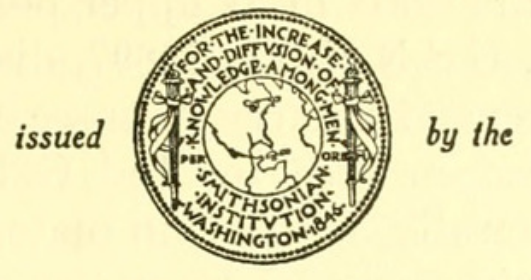

SMITHSONIAN INSTITUTION

U. S. NATIONAL MUSEUM

Vol. 84

Washington : 1936

No. 3003

\title{
TWO NEW SPECIES OF HAWKS FROM THE MIOCENE OF NEBRASKA
}

\author{
By Alexander Wetmore
}

Assistant Secretary, Smithsonian Institution

From collections made by Ted Galusha, the United States National Museum recently has obtained two fragmentary metatarsi that represent, respectively, new species in the families Accipitridae and Falconidae. Both are of more than usual interest, the first because it reveals an additional American species of the subfamily Aegypiinae, whose living representatives are found only in the Old World, and the second because it carries the group of falcons in America back into the Miocene.

In connection with work on the falcon I have had the benefit of examination of the type of Falco falconellus Shufeldt, of uncertain status, through the kindness of Dr. Richard S. Lull and Dr. Malcolm R. Thorpe, of the Peabody Museum, Yale University. The drawings herein were made for me by Sidney Prentice.

\section{Family ACCIPITRIDAE}

\section{Genus PALAEOBORUS Coues}

\section{PALAEOBORUS HOWARDAE, new species}

Characters.-Distal end of tarso-metatarsus (fig. 13) similar to that of Palaeoborus umbrosus (Cope) ${ }^{1}$ but slightly larger; outer intertrochlear sulcus broader; middle trochlea relatively larger;

\footnotetext{
1 Cathartes umbrosus Cope, Proc. Acad. Nat. Sci. Philadelphia, vol. 26, Oct. 10, 1874, p. 151. Metatarsus illustrated in Cope, Rep. U. S. Geogr. Surv. West 100th Merid., vol. 4, pt. 2,1877 , pl. 67 , figs. $15,15 \mathrm{a}, 15 \mathrm{c}$.
} 
tendinal impression on inner posterior angle narrower and more heavily impressed on the shaft in its upper portion.

Description.-Type, U.S.N.M. no. 13897, distal end of right tarsometatarsus, from Miocene of Quarry A in sec. 29, T. 31, R. 47, Dawes County, Nebr., collected in 1934 by Ted Galusha. Outer trochlea narrow, compressed laterally, with a thin plate projecting posteriorly, elliptical in outline when viewed from the side; inner face much excavated, intertrochlear sulcus separating it from middle trochlea distinctly wider than that between internal and middle trochlea; middle trochlea nearly circular in outline when viewed from the side, relatively strong and robust; distinctly elevated from the level of the shaft both posteriorly and anteriorly, with a pronounced groove extending completely around the articular surface; both faces much
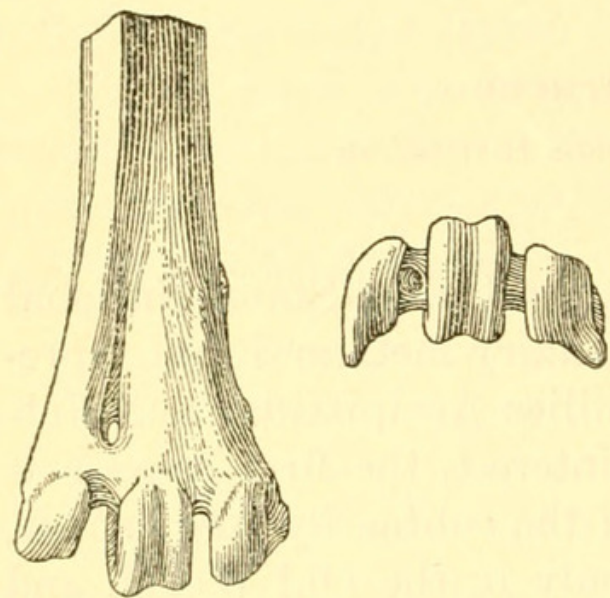

Figure 13.-Palaeoborus howardae, new species: Distal end of tarso-metatarsus of type (U.S.N.M. no. 13897). About natural size.

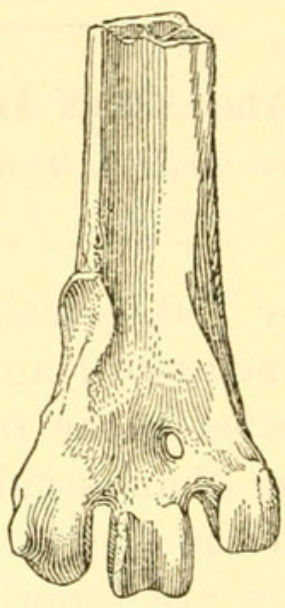

excavated; inner trochlea compressed, with a distinct impression in center of outer face, beyond which the bone extends as a narrowed projection triangular in general outline; inner face much excavated; intertrochlear sulcus between it and middle trochlea decidedly narrowed; lower end of shaft flattened and expanded, forming a

broad base from which project the trochlea; inferior foramen of good size, located relatively low on the shaft, with a slight depression around it behind, and a distinct groove leading into it from above on the anterior face; body of shaft strong and robust, with outer face plain, the boundaries being sharp-ridged both in front and in back; a strongly impressed tendinal groove on inner angle; posterior face of shaft with a broad, shallow groove above; impression for articulation of hallux strongly marked; anterior face of shaft a somewhat irregular plane sloping toward the inner margin. Bone well fossilized, dull gray in color, whiter on the trochlea.

Measurements.-Smallest transverse breadth of shaft, $9.7 \mathrm{~mm}$; transverse breadth across trochlea, $20.4 \mathrm{~mm}$.

Remarks.-This species seems to have been one with strong and robust foot, indicating a distinctly predatory type of life. The short, heavy form of the inner trochlea, with the relatively slightly projecting wing, and the relatively large size of the middle trochlea com- 
pared with the others, place it in the subfamily Aegypiinae, adding another species to this group in the New World. It has the strong, robust form of Neogyps errans, but in detail of structure it is more similar to the more slightly built Neophrontops americanus.

From Neophrontops americanus, in addition to its much larger size, $P$. howardae differs in having the larger and more robust middle trochlea projecting abruptly on the anterior face, instead of merging gradually into the shaft; the external intertrochlear sulcus much wider; the axis of the ala interna of second trochlea making a right angle with axis of shaft, so that its point is elevated above lower margin of trochlea instead of nearly on the same level; the inferior foramen less elevated; and a strongly impressed tendinal groove on posterior face of outer margin of shaft.

Neophrontops dakotensis Compton ${ }^{2}$, described from the lower Pliocene of South Dakota, is decidely smaller.

Palaeoborus howardae agrees so closely with $P$. umbrosus, which Dr. Hildegarde Howard ${ }^{3}$ has included in the subfamily Aegypiinae, that after some consideration, including a careful study of Cope's figures, it is described in the genus Palaeoborus. I have not been successful in locating Cope's type material, but should this subsequently be found comparison of the actual specimens may indicate that the species here named should be placed in a separate genus.

I have pleasure in naming this species for Dr. Hildegarde Howard in recognition of her excellent work on the eagles and eaglelike vultures of the Pleistocene deposits of California.

\section{Family FALCONIDAE}

\section{Genus FALCO Linnaeus}

FALCO RAMENTA, new species

Characters.-Distal end of tarso-metatarsus (fig. 14) generally similar to modern Falco columbarius Linnaeus ${ }^{4}$ but decidedly smaller; inferior foramen viewed from posterior surface more elevated on shaft.

Description.-Type, U.S.N.M. no. 13898, distal portion of right metatarsus, from Miocene of Merychippus quarry, in southwest corner of NW $1 / 4$, sec. 14, T. 31 , R. 47, Dawes County, Nebr., collected in 1934 by Ted Galusha. Shaft slender but strong; anterior face with a faintly impressed, very shallow groove toward inner margin that disappears completely well above trochlea, the surface becoming smoothly curved at that point; opening for anterior foramen very

\footnotetext{
${ }^{2}$ Amer. Journ. Sei., vol. 30, Oct. 1935, p. 344, fig. 1.

3 Carnegie Inst. Washington Publ. 429, Oct. 1932, p. 70 et seq.

${ }^{4}$ Systema naturae, ed. 10, vol. 1, 1758, p. 90 (South Carolina).
} 
small, located in a slightly indicated, narrow groove; posterior surface of shaft with raised margins, making a broad, shallow trough; facet for articulation of first toe well marked, rather elevated on side of shaft; supporting base for trochleae broad and flattened, with the curve of the trochlea open; inner trochlea with distal margin even with middle trochlea, rounded, with internal face somewhat excavated, anterior surface smoothly rounded, with a flattened plate, most of which has been broken away, projecting from its free margin; internal intertrochlear sulcus open, but relatively narrow; middle trochlea small, projecting somewhat anteriorly beyond those on either side, nearly round in lateral outline, its free margin deeply grooved, on the posterior face descending abruptly into shaft; the entire trochlea distinctly smaller than those on either side; outer trochlea viewed from outer face a flat, crudely elliptical plate, its
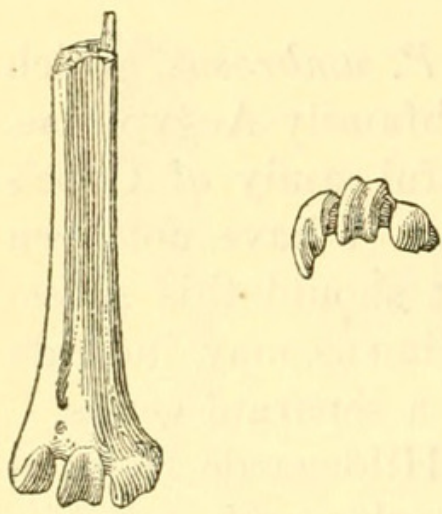

Figure 14.-Falco ramenta, new species: Distal end of tarso-metatarsus of type (U.S.N.M. no. 13898). Twice natural size.

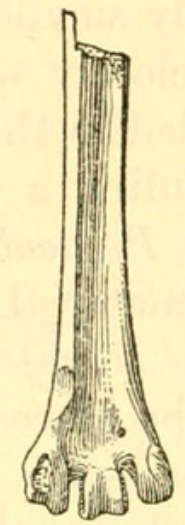

opening, located at a point above the base of the outer trochlea. Specimen well fossilized; color dull ivory, mottled with gray.

Measurements.-Greatest transverse breadth across trochlea, 5.3 $\mathrm{mm}$; smallest transverse breadth of shaft, $2.3 \mathrm{~mm}$.

Remarks.-The species here described, from the evidence to be found in the lower end of the metatarsus, was about the size of the male of the small race of sparrow hawk resident in Florida, Falco sparverius paulus (Howe and King). The elevation of the inferior foramen on the shaft is similar to what is found in the sparrow hawks, the pigeon hawks having this opening nearer the base of the outer trochlea. The metatarsus in the fossil, however, is distinctly heavier, and the facet for the articulation of the first digit is extended farther up the shaft, characters that distinguish $F$. columbarius and $F$. sparverius as species. It seems, therefore, that $F$. ramenta was related more nearly to the pigeon hawks, being distinguished from any of the living forms in this group by decidedly smaller size. This difference is more evident in the smaller, more 
delicate form of the trochlea than from measurements and is readily apparent on comparison of specimens.

Ted Galusha, from whom the type of Falco ramenta was obtained, informs me that his "Merychippus quarry", where the specimen was found, is characterized by remains of Merychippus primus, Нуроhippus, Merycodus, and Mylogaulus, among other mammals. He considers it probably equivalent to the Sheep Creek beds. The exact level in the Miocene of this deposit remains to be definitely established, but it seems probable that it is located in the middle or lower upper Miocene.

Other pigmy species related to forms still living have been found in the same general period of geologic time. These include Ortalis tantala, a chachalaca less than half the size of the modern species in this group; Paractiornis perpusillus, an oystercatcher with the stature of a sanderling; and Conuropsis fratercula, which resembles the Carolina paroquet but is only three-fourths as large. It would appear that the latter half of Tertiary time was highly favorable to diversity of form among birds, so that there were developed many size types that with the incidence of more rigorous conditions in Pleistocene and Recent times became extinct.

\section{STATUS OF FALCO FALCONELLUS SHUFELDT}

In considering the affinities of Falco ramenta, I have had the privilege of examining the type material of $F$. falconellus Shufeldt through the kindness of Dr. Richard S. Lull and Dr. Malcolm R. Thorpe. This species, described as Falco falconella ${ }^{5}$ was named according to Shufeldt from "five (5) fossil bones or fragments of bones which, in life, evidently belonged to either a small $\mathrm{Owl}$ or a small Falcon or Hawk." The specimens come from the Bridger Eocene of Wyoming. The type material, all of which is fragmentary, includes the following:

(1) A bit of an articular surface or process that is not avian; without comparing it definitely I consider it mammalian.

(2) A phalanx from the foot of some small bird.

(3) A much compressed unguis from the foot of a larger bird than no. 2.

(4) Head of the left coracoid of a small bird.

(5) Distal end of the left humerus of a small bird.

After prolonged and careful examination and many comparisons with modern birds, I am forced to the conclusion that $F$. falconellus cannot be identified. The material includes representation from at least three orders of birds. The fragmentary humerus is the only

5 Trans. Connecticut Acad. Arts and Sci., vol. 19, Feb. 1915, p. 40, pl. 15, figs. 139-143. 
bone of the five that might offer characters to indicate relationship, but this is so crushed and broken that I have not been able to establish the family, or even the order, to which it belongs. The only pertinent character evident is that of reduction in the radial condyle, which has the articulating surface cut away. There is little else that may be said about it, except to indicate that it is not from a species of the order Falconiformes. With considerable reluctance I am forced to the conclusion that it is necessary to relegate Falco falconellus Shufeldt to the limbo of those species that may not be given a place in our systematic classification. 


\section{$2 \mathrm{BHL}$ Biodiversity Heritage Library}

Wetmore, Alexander. 1936. "Two new species of hawks from the Miocene of Nebraska." Proceedings of the United States National Museum 84(3003), 73-78. https://doi.org/10.5479/si.00963801.84-3003.73.

View This Item Online: https://www.biodiversitylibrary.org/item/32837

DOI: https://doi.org/10.5479/si.00963801.84-3003.73

Permalink: https://www.biodiversitylibrary.org/partpdf/4211

\section{Holding Institution}

Smithsonian Libraries

\section{Sponsored by}

Smithsonian

\section{Copyright \& Reuse}

Copyright Status: NOT_IN_COPYRIGHT

Rights: https://www.biodiversitylibrary.org/permissions/

This document was created from content at the Biodiversity Heritage Library, the world's largest open access digital library for biodiversity literature and archives. Visit BHL at https://www.biodiversitylibrary.org. 